Reprod. Nutr. Dévelop., 1983, 23 (6), 979-993.

\title{
Early effects of 1,25 dihydroxyvitamin $D$ on bone calcium in vitamin D-deficient rats
}

\author{
P. J. MARIE
}

Unité de Recherche sur le Métabolisme phosphocalcique, U. 18 INSERM, 6, rue Guy-Patin, 75010 Paris.

Summary. The early effects of 1,25 dihydroxyvitamin $D\left[1,25(\mathrm{OH})_{2} \mathrm{D}\right]$ on calcium transfer in and out of the skeleton were studied in rats to determine whether mobilized bone calcium was reutilized during new bone mineralization. Vitamin-D deficient rats were labeled with ${ }^{45}$ calcium 10 to 14 days prior to treatment (experiment 1) or at the same time (experiment 2) they were injected with $0.125 \mu \mathrm{g}$ of $1,25(\mathrm{OH})_{2} \mathrm{D}$. Blood and bone samples were collected from 30 min to $24 \mathrm{~h}$ following $1,25(\mathrm{OH})_{2} \mathrm{D}$ injection. Stable and radioactive calcium were determined in serum, and caudal vertebrae were subjected to histomorphometric and autoradiographic studies. In the rats of experiment 1 , serum specific radioactivity peaked from 1 to $3 \mathrm{~h}$ after $1,25(\mathrm{OH})_{2} \mathrm{D}$ injection, while there was no change in control rats receiving the vehicle alone. In the untreated vitamin D-deficient rats of experiment 2, the rate of ${ }^{45} \mathrm{calcium}$ loss in serum was higher than normal but returned to normal after $1,25(\mathrm{OH})_{2} \mathrm{D}$ injection. Serum calcium and osteoclast number remained initially unchanged, suggesting that $1,25(\mathrm{OH})_{2} \mathrm{D}$ acted by increasing the efflux of calcium from bone and/or by stimulating the activity of existing osteoclasts. The rapid mobilization of ${ }^{45}$ calcium, accompanied by an increase in the extent of actively mineralizing surfaces, was followed by an increase in the extent of endosteal surface with osteoblasts and by specific incorporation of radioactive calcium at sites of new bone calcification. This study indicates that in vitamin D-deficient rats, the initial promotion of bone mineralization by $1,25(\mathrm{OH})_{2} \mathrm{D}$ resulted in part from the rapid mobilization of calcium from old mineralized bone.

\section{Introduction.}

Vitamin $\mathrm{D}$ metabolites are known to influence the regulation of both bone resorption and mineralization in rats. 1,25 dihydroxyvitamin $D\left[1,25(\mathrm{OH})_{2} \mathrm{D}\right]$, the physiologically-active metabolite of vitamin D (De Luca and Schnoes, 1976), is a potent stimulator of bone calcium resorption in intact (Holick, Garabedian and De Luca, 1976 ; Tanaka and De Luca, 1971) and thyroparathyroidectomized (Reynolds, Pavlovitch and Balsan, 1976) animals. It has been shown that 
$1,25(\mathrm{OH})_{2} \mathrm{D}$ increases the number and activity of osteoclasts in the absence of parathormone (PTH) (Weisbrode, Capen and Norman, 1978; Holtrop et al., 1981). The other mechanisms by which $1,25(\mathrm{OH})_{2} \mathrm{D}$ can mobilize calcium from bone are still unclear (Brommage and Neuman, 1979). Vitamin D-deficiency is associated with rickets and osteomalacia which are believed to result from an inadequate supply of calcium and phosphorus for bone mineralization (De Luca and Schnoes, 1976). The beneficial effects of $1,25(\mathrm{OH})_{2} \mathrm{D}$ on bone calcification appear to be due to increased intestinal absorption of calcium and phosphate (Reynolds, 1974). However, evidence has been presented that $1,25(\mathrm{OH})_{2} \mathrm{D}$ can promote bone mineralization in rats independently of its effects on intestinal calcium and phosphate absorption (Boris et al., 1978). We have recently shown that continuous infusion of $1,25(\mathrm{OH})_{2} \mathrm{D}$ in mice stimulates osteoclastic bone resorption and produces a dose-dependent acceleration of the calcification rate apart from changes in extracellular mineral concentrations (Marie and Travers, 1983). These studies suggest that the promotion of bone mineralization induced by $1,25(\mathrm{OH})_{2} \mathrm{D}$ administration may result from the previous mobilization of calcium and phosphate salts from old mineralized bone, thus increasing the mineral concentration at the bone surface (Bordier et al., 1976).

In order to test this hypothesis, the movements of radioactive calcium in and out of the skeleton were studied in vitamin D-deficient rats following the administration of a single dose of $1,25(\mathrm{OH})_{2} \mathrm{D}$.

\section{Material and methods.}

Animals. - One hundred and fifty 3-week old male Charles River rats (St-Aubinles-Elbeuf, France) were kept in plastic cages in darkness and were fed ad libitum a vitamin D-deficient rachitogenic diet (INRA, La Minière, France) containing $0.47 \%$ calcium and $0.30 \%$ phosphorus. After three weeks, the animals were divided into two experimental groups of 3 lots each.

Experiment 1. - Seventy-five rats were injected intraperitoneally with $2 \mu \mathrm{Ci}$ of ${ }^{45} \mathrm{CaCl}_{2}$ (specific activity: $52 \mathrm{Ci} / \mathrm{g}$; CEA, Gif-sur-Yvette, France) in saline solution 10, 12 and 14 days prior to sacrifice in order to label the skeleton with radioactive calcium. Ten days after the last injection, $0.5 \mathrm{ml}$ of blood was collected from the tail vein and serum calcium and ${ }^{45}$ calcium were determined and basal circulating specific radioactivity was calculated. At that time, 30 animals (group 1) were injected intraperitoneally with $0.125 \mu \mathrm{g}$ of $1,25(\mathrm{OH})_{2} \mathrm{D}$ (kindly provided by Prof. A. W. Norman, Riverside, California, USA) in ethanol, while 21 control rats (group 2) were injected with an equivalent volume of the vehicle alone. A group of 24 rats (group 3) was vitamin D-repleted by giving a daily intrastomachal supplement of $0.125 \mu \mathrm{g}$ of 25 hydroxyvitamin $D$ for the 3 weeks preceding sacrifice. These animals were injected with an equivalent volume of the vehicle alone at the same time as the rats of group 2 . All the animals received an ip injection of calcein $(30 \mathrm{mg} / \mathrm{kg})$, a marker of bone calcification, immediately after the injection of $1,25(\mathrm{OH})_{2} \mathrm{D}$ or of the vehicle and were killed at 42-43 days of age by exsanguination under light ether anesthesia at regular intervals ranging from 30 min to $24 \mathrm{~h}$ after the injection of $1,25(\mathrm{OH})_{2} \mathrm{D}$ or the vehicle. 
Experiment 2. - In this experiment, the rats were not prelabeled with ${ }^{45}$ calcium. After 3 weeks of vitamin D-deficiency, $0.5 \mathrm{ml}$ of blood was collected from the tail vein for determination of serum calcium. Each of the 75 rats was then given an ip injection of $6 \mu \mathrm{Ci}$ of ${ }^{45} \mathrm{CaCl}_{2}$. Immediately after this injection, $a$ group of 27 rats (group 4) was injected intraperitoneally with $0.125 \mu \mathrm{g}$ of $1,25(\mathrm{OH})_{2} \mathrm{D}$, while a group of 24 rats (group 5) received an equivalent volume of the vehicle alone. Twenty-four rats (group 6) were vitamin D-repleted as indicated above and were injected with the vehicle alone at the same time as the rats of groups 4 and 5 . Immediately after the administration of $1,25(\mathrm{OH})_{2} \mathrm{D}$ or ethanol, all the rats were injected with calcein. The animals (42-43 days old) were then sacrificed by cardiac puncture under light anesthesia at intervals ranging from $30 \mathrm{~min}$ to $24 \mathrm{~h}$ after the injection of $1,25(\mathrm{OH})_{2} \mathrm{D}$ or the vehicle. The blood and bone samples of rats of experiments 1 and 2 were collected for biochemical and histological studies.

Biochemical assays. - Samples of serum were assayed for calcium by atomic absorption spectrophotometry (Perkin-Elmer model 303, Norwalk, CT, USA) after dilution in $0.5 \%$ lanthane chloride solution. All the serum samples were assayed for radioactivity using an automatic $\beta$ scintillation counter (Intertechnique model $S L 40$ ), and all counts were corrected for decay. The specific radioactivity $(\mathrm{dpm} / \mu \mathrm{g})$ in the serum was calculated by the ratio of ${ }^{45} \mathrm{calcium}(\mathrm{dpm} / \mathrm{ml})$ to calcium $(\mathrm{mg} / \mathrm{l})$. The results were expressed in percentage of the initial value obtained before 1,25 $(\mathrm{OH})_{2} \mathrm{D}$ or ethanol injection (experiment 1) or in percentage of the dose of ${ }^{45}$ calcium injected (experiment 2 ).

Bone histology. - At sacrifice, the proximal half of the tail was freed of soft tissues, fixed in neutral $(\mathrm{pH} 7.2)$ formaldehyde at $4{ }^{\circ} \mathrm{C}$ for $24 \mathrm{~h}$, dehydrated in alcohol at cold temperature and embedded undecalcified in methyl-methacrylate. Histological bone studies were performed on the seventh caudal vertebra as previously described (Marie, Travers and Glorieux, 1981). This bone was chosen because it has the unique advantages of being symmetrical in cross sections and not complicated by cortical drift (Hammond and Storey, 1974). Moreover, the metaphysis is mainly composed of trabecular bone which is very sensitive to the influence of vitamin D (Queillé et al., 1978). Five- $\mu$ thick longitudinal sections of the midshaft of the seventh vertebra were stained with toluidine blue at $\mathrm{pH} 2.8$, while $15-\mu$ thick sections were mounted unstained for fluorescence microscopy. The following parameters of bone resorption and formation were quantitatively analyzed at the diaphyseal level of the vertebra using a Zeiss II integrating eyepiece (Carl Zeiss, W. Germany) at $256 \times$ magnification. We determined the total number of osteoclasts per square millimeter of endosteal bone section (osteoclast number $/ \mathrm{mm}^{2}$ ), the percentage of total endosteal and periosteal bone surfaces exhibiting a fluorescent calcein label under ultraviolet light (calcification front), and the percentage of endosteal bone surface showing plump osteoblasts (osteoblastic surface). The histomorphometric values presented are the means of measurements of 4 nonadjacent sections. The probabilities of difference between untreated and treated rats were calculated by Student's t-test.

From each bone specimen, ten $5-\mu m$ thick unstained histological sections were used for autoradiographs. The sections were coated with Ilford $K 5$ liquid 
emulsion by the dipping technique (Rogers, 1967), exposed for 21 days at $4{ }^{\circ} \mathrm{C}$, developed, fixed, dried and counter-stained with toluidine blue before microscopic examination.

\section{Results.}

Biochemical analysis.

The mean serum calcium measured on pooled samples from vitamin Ddeficient rats prior to treatment was $6.71 \pm 0.09 \mathrm{mg} / \mathrm{dl}$ compared to $9.78 \pm 0.11 \mathrm{mg} / \mathrm{dl}$ in vitamin $\mathrm{D}$-repleted rats $(\mathrm{P}<0.001)$.

- Effect of 1,25 (OH $)_{2} \mathrm{D}$ on serum calcium concentration. - Figure 1 shows the variation in time of serum calcium in treated and untreated rats. Serum calcium did not change significantly from time 1 to $8 \mathrm{~h}$ after ethanol injection in vitamin D-deficient rats (mean value : $6.59 \pm 0.08 \mathrm{vs} 6.71 \pm 0.09 \mathrm{mg} / \mathrm{dl}$, n.s.) or vitamin D-repleted rats $(9.87 \pm 0.43$ vs $9.78 \pm 0.11 \mathrm{mg} / \mathrm{dl}$, n.s. $)$. In treated animals, there was a slight but non-significant drop in serum calcium at times 1 and $2 \mathrm{~h}$ after $1,25(\mathrm{OH})_{2} \mathrm{D}$ injection. Thereafter, the final serum calcium concentration was significantly higher than the initial value from time 4 $(6.62 \pm 0.56$ vs $5.65 \pm 0.09 \mathrm{mg} / \mathrm{dl} ; \mathrm{P}<0.05)$ to $24 \mathrm{~h}$ after $1,25(\mathrm{OH})_{2} \mathrm{D}$ injection. Serum calcium level reached the normal range at time $16 \mathrm{~h}$ after $1,25(\mathrm{OH})_{2} \mathrm{D}$ injection $(9.05 \pm 0.43 \mathrm{mg} / \mathrm{dl} v s$ controls : $9.78 \pm 0.11 \mathrm{mg} / \mathrm{dl}$, n.s. $)$ and rose slightly above normal values at time $24 \mathrm{~h}$ post treatment $(11.3 \pm 0.02 \mathrm{mg} / \mathrm{dl}$ vs $9.78 \pm 0.11 \mathrm{mg} / \mathrm{dl} ; \mathrm{P}<0.05)$.

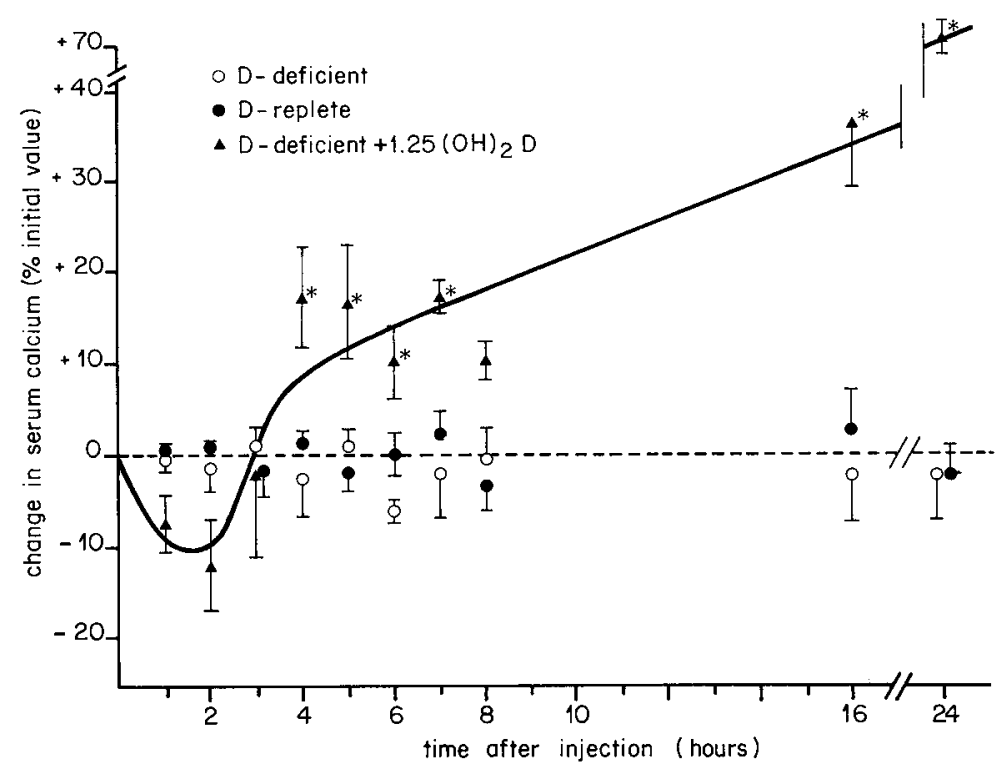

FIG. 1. - Changes in serum calcium in rats treated with $1,25(\mathrm{OH})_{2} \mathrm{D}$ compared to control rats receiving the vehicle alone (pooled data from experiments 1 and 2). The values are the means \pm SD of 4-5 rats. Values with an asterisk are significantly different from those of untreated vitamin $D$-deficient rats $(P<0.05$ or better level of significance). 
- Effect of 1,25 (OH) ${ }_{2} \mathrm{D}$ on radioactive calcium in prelabeled rats (experiment 1). - The profile of the specific radioactivity in rats of groups 1 to 3 is shown on figure 2 . Specific radioactivity remained constant in vitamin D-deficient or repleted rats injected with the vehicle alone. In contrast, the specific radioactivity in serum rose markedly and significantly from time 1 to $4 \mathrm{~h}$ after $1,25(\mathrm{OH})_{2} \mathrm{D}$ administration and fell progressively thereafter. The rise in specific activity in treated rats resulted mainly from the increased concentration of the serum isotope since serum calcium concentration was not significantly changed (fig. 1). At time $4 \mathrm{~h}$ and later, however, the gradual decrease in serum specific radioactivity may have resulted in part from the progressive rise in serum calcium observed at that time.

- Effect of 1,25 (OH) $)_{2} \mathrm{D}$ on the disappearance of radioactive calcium from the serum (experiment 2). - The results are summarized on figure 3. Specific radioactivity declined more rapidly in vitamin D-deficient than in vitamin D-repleted rats during the first $4 \mathrm{~h}$ after the injection of ${ }^{45} \mathrm{calcium}$. Compared to untreated vitamin D-deficient rats, $1,25(\mathrm{OH})_{2} \mathrm{D}$ reduced significantly the rate of decrease of specific radioactivity in serum from time 1 to time $4 \mathrm{~h}$ after its injection. At $1 \mathrm{~h}$ after $1,25(\mathrm{OH})_{2} \mathrm{D}$ injection, specific radioactivity was higher than normal, while later it was not different from the normal level.

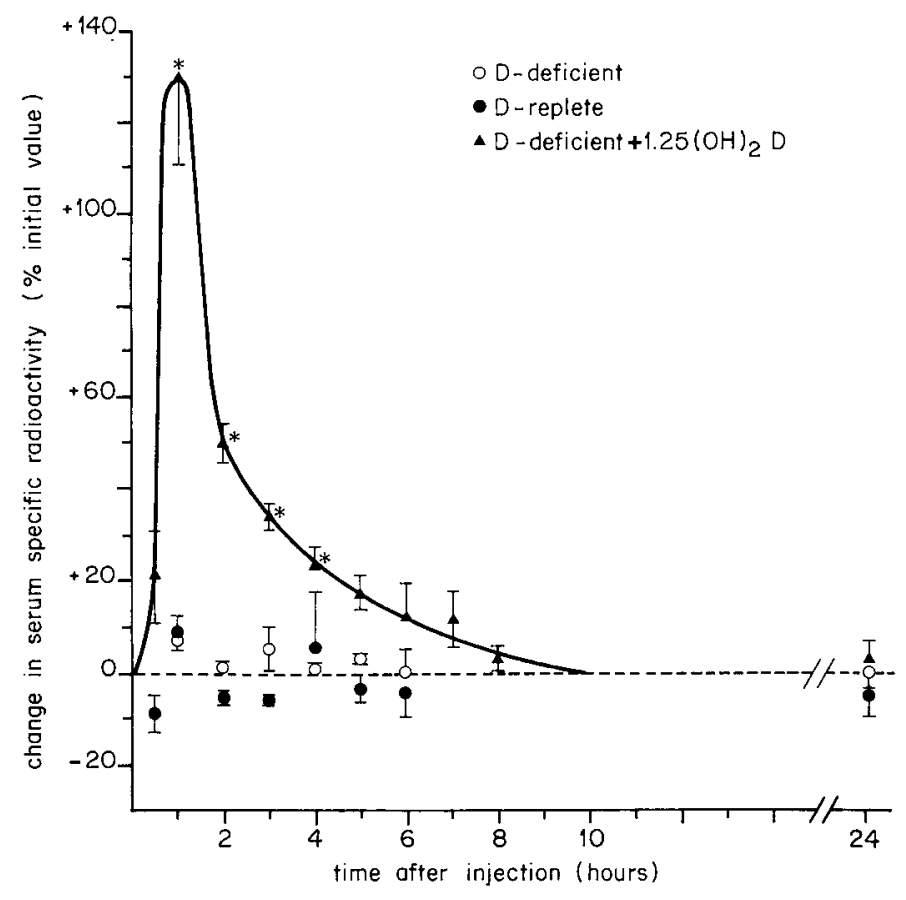

FIG. 2. - Changes in serum specific radioactivity in rats labeled with ${ }^{45}$ calcium 10 to 14 days prior to the injection of $1,25(\mathrm{OH})_{2} \mathrm{D}$ or the vehicle alone (experiment 1 ). The values are the means $\pm S D$ of 3 rats. Values with an asterisk are significantly different from those of untreated vitamin $D$-deficient rats $(P<0.05$ or better level of significance). 


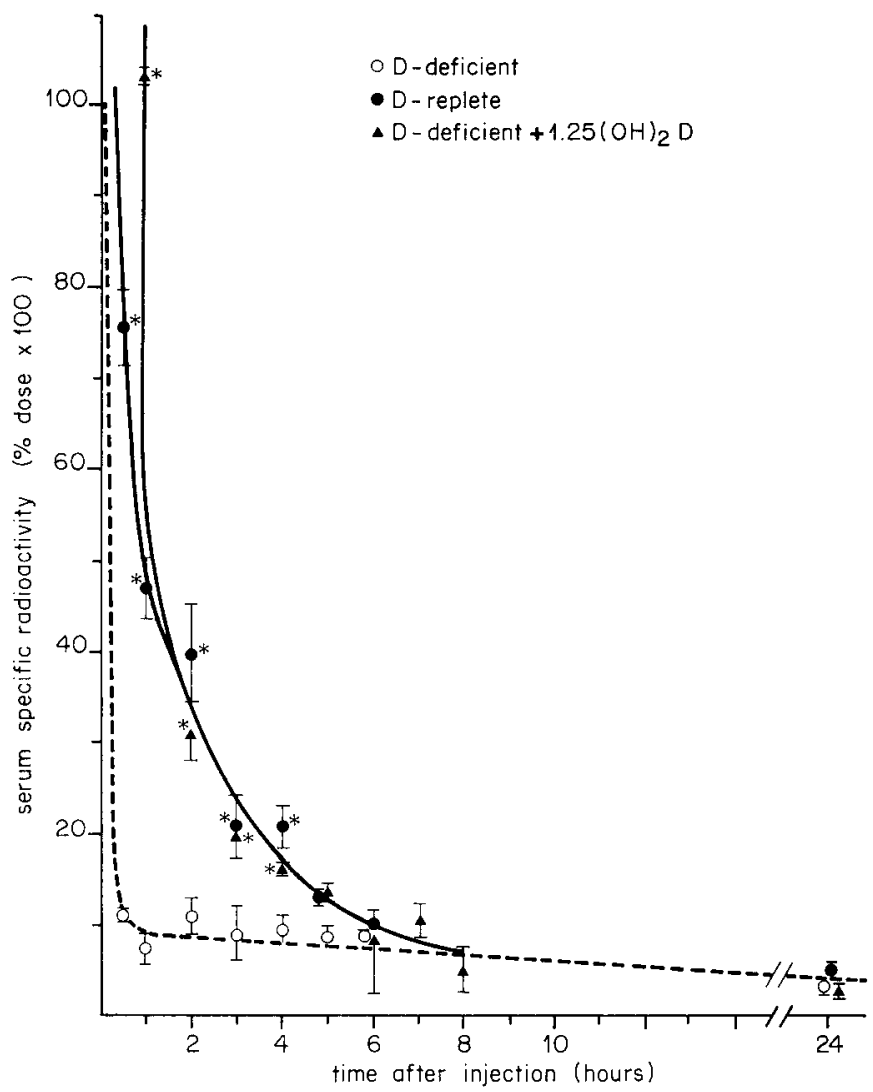

FIG. 3. - Changes in serum specific radioactivity in rats injected with ${ }^{45}$ calcium and $1,25(\mathrm{OH})_{2} \mathrm{D}$ or the vehicle (experiment 2). The values are the means $\pm S D$ of 3 rats. Values with an asterisk are significantly different from those of untreated vitamin $D$-deficient rats $(P<0.05$ or better level of significance).

Skeletal analysis. - Figure 4 compares the relative extent of fluorescent labeled bone surfaces in the different groups of rats in the two experiments. In untreated vitamin D-deficient rats, the fluorescent calcification front reached a maximal value at $5 \mathrm{~h}$ after calcein injection and remained at less than $20 \%$ of the bone surface thereafter. In contrast, vitamin D-repleted rats showed a rapid incorporation of calcein at mineralization sites. The uptake of fluorescent label reached a maximal value $(58 \%)$ at $5 \mathrm{~h}$ after calcein injection. At time $24 \mathrm{~h}$, the extent of the calcification front tended to decrease slowly, probably because part of the fluorescent calcified bone had been resorbed at that time. In rats treated with $1,25(\mathrm{OH})_{2} \mathrm{D}$, the fluorescent calcification front was significantly increased compared to untreated controls as soon as $1 \mathrm{~h}$ after injection of the metabolite. At that time, the calcification front in treated rats was similar to values in normal animals. Thereafter, however, the calcification front in treated animals remained 


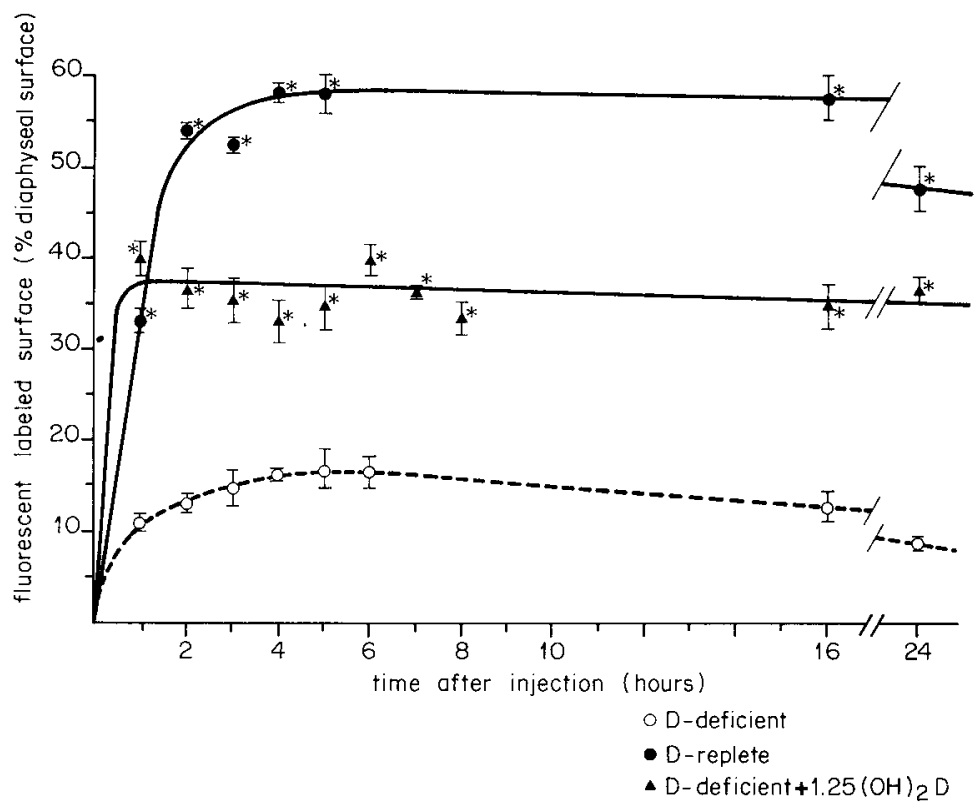

FIG. 4. - Variations in the percentage of total diaphyseal surface exhibiting a fluorescent calcein label after injection of $1,25(\mathrm{OH})_{2} \mathrm{D}$ or vehicle in rats (experiments 1 and 2$)$. The values are the means $\pm S D$ of 5-6 rats. Values with an asterisk are significantly different from those of untreated vitamin $D$-deficient rats $(P<0.05$ or better level of significance).

fairly constant but lower than normal (fig. 4). The mean osteoblastic surface was lower in untreated vitamin D-deficient rats than in normal ones $111.9 \pm 2.9 \mathrm{vs}$ $20.2 \pm 3.9 \% ; P<0.02$ ). The osteoblastic surface remained unchanged at all times after ethanol injection in vitamin D-deficient and repleted animals. Compared to controls at the same time, no significant change was noted in the osteoblastic surface at time $1-2 \mathrm{~h}(13.6 \pm 3.1$ vs $10.0 \pm 2,1 \%$, n.s. $)$ or $3-4 \mathrm{~h}$ after $1,25(\mathrm{OH})_{2} \mathrm{D}$ injection $(17.9 \pm 4.0$ vs $11.4 \pm 2.2 \%$, n.s.). On the other hand, the osteoblastic surface showed a significant increase to normal at time $5-6 \mathrm{~h}(19.2 \pm 2.9$ vs $14.3 \pm 3.2 \% ; \mathrm{P}<0.02)$ after $1.25(\mathrm{OH})_{2} \mathrm{D}$ injection and remained unchanged thereafter.

The changes in osteoclast number in untreated rats and treated rats are presented on figure 5 . The number of osteoclasts per $\mathrm{mm}^{2}$ of bone area tended to be greater in normal rats than in vitamin D-deficient animals but this was significant only at times 1, 3, 16 and $24 \mathrm{~h}$. Eight hours after 1,25 $(\mathrm{OH})_{2} \mathrm{D}$ injection, the number of osteoclasts rose significantly compared to the average basal value in untreated rats $(P<0.05)$. This increase in osteoclast number persisted at times 16 and $24 \mathrm{~h}$ after $1,25(\mathrm{OH})_{2} \mathrm{D}$ injection. At these times, it was not different from the value found in normal rats.

Examination of the histological sections revealed marked differences between vitamin D-repleted and vitamin D-deficient rats (photos $A$ and $B$ ). Compared to normal rats, untreated vitamin D-deficient rats exhibited an excessive amount of 


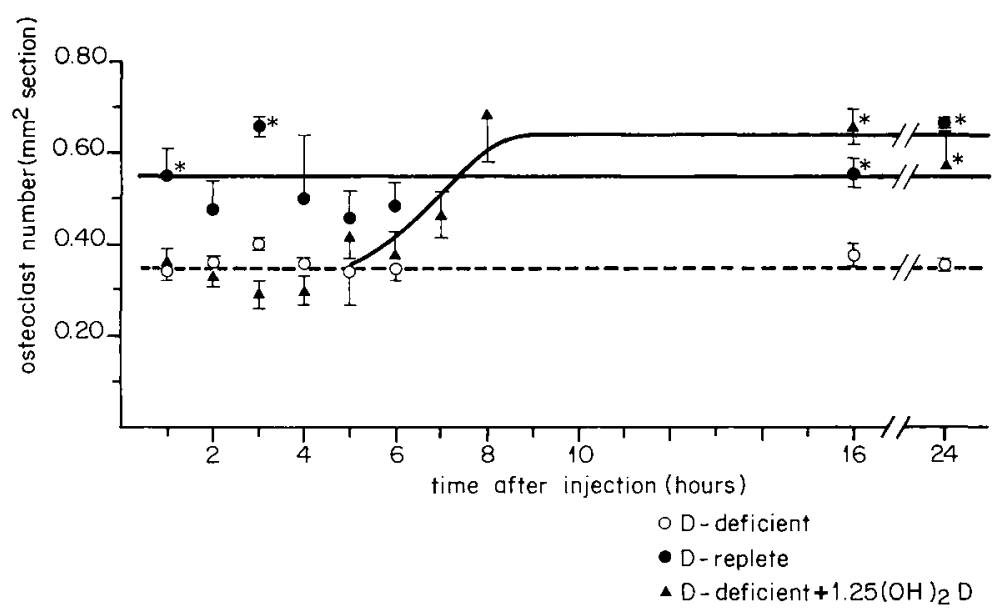

FIG. 5. - Changes in osteoclast number per $\mathrm{mm}^{2}$ of bone section in rats of experiments 1 and 2 after injection of $1,25(\mathrm{OH})_{2} \mathrm{D}$ or the vehicle. The values are the means \pm SD of 5-6 rats. Values with an asterisk are significantly different from those of untreated vitamin D-deficient rats $(P<0.05$ or better level of significance) .

unmineralized bone tissue and almost no calcification front stained with toluidine blue at the osteoid-calcified bone interface. Microradiographs A to D show autoradiographs of histological sections from prelabeled rats. Similar images were obtained at the same period of time in rats that were not prelabeled with ${ }^{45}$ calcium. Background radiation was negligible and there was little non-specific distribution of the radioisotope, indicating that the autoradiographic method, although not perfect, was sufficient to permit visualization of the specific incorporation of ${ }^{45}$ calcium into bone areas. In prelabeled rats, radioactive calcium was found mainly on the calcified matrix in both vitamin D-repleted (photo A) and vitamin D-deficient (photo B) rats. The distribution of the radioisotope appeared to be homogeneous and no specific localization of the labeled material was observed. Both the old bone and the more recently calcified matrix, visualized by the presence of a calcification front, were labeled equally. Shortly after the administration of the isotope in rats of experiment 2 , both osteoid and calcified bone were labeled. Preferential labeling of the calcified matrix developed progressively with time, and at $5 \mathrm{~h}$ after the injection of ${ }^{45}$ calcium labeled material was found mainly in calcified bone. Thereafter, the histological and autoradiographic aspects of the bone in rats of experiments 1 and 2 did not appear to differ.

Treatment with 1,25 $(\mathrm{OH})_{2} \mathrm{D}$ caused important changes in both the histological appearance of the caudal vertebra and the distribution of ${ }^{45}$ calcium. In both prelabeled rats (experiment 1) and those that were not prelabeled (experiment 2), a new histologically stained calcification front was identified at the osteoid-calcified bone interface $5 \mathrm{~h}$ after 1,25 $(\mathrm{OH})_{2} \mathrm{D}$ injection, and new bone calcification appeared gradually with time (photos $C$ and D). As soon as the 

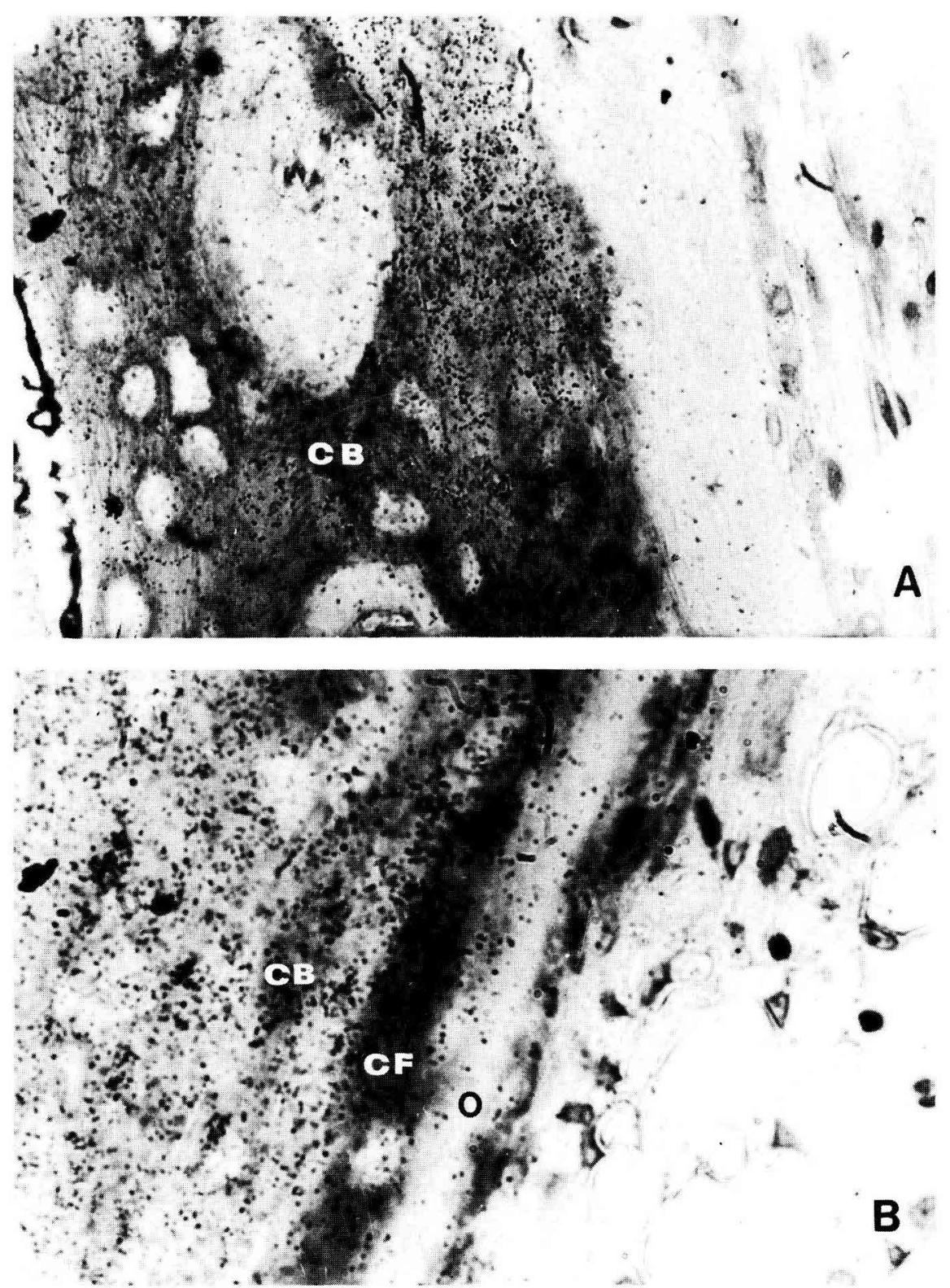

PHOTO A. - Autoradiograph of diaphyseal vertebral bone from an untreated vitamin D-deficient rat prelabeled with ${ }^{45}$ calcium 10 to 14 days prior to treatment (experiment 1 ). Osteomalacia is evidenced by the large osteoid seams $(0)$ and the absence of a calcification front at the osteoidcalcified bone interface. Note the homogeneous distribution of ${ }^{45}$ calcium visualized by black grains over the calcified bone $(C B)$. Toluidine blue staining; thickness of undecalcified section : $5 \mu \mathrm{m} . \times 512$.

PHOTO B. - Autoradiograph of a diaphyseal vertebral bone from a vitamin D-repleted rat prelabeled with ${ }^{45} \mathrm{calcium} 10$ to 14 days prior to injection of the vehicle. Note the thin osteoid seams (O), the presence of a calcification front (CF) and the homogeneous distribution of ${ }^{45} \mathrm{calcium}$ over the calcified bone (CB). Toluidine blue staining; thickness of undecalcified section : $5 \mu \mathrm{m}$. $\times 512$. 

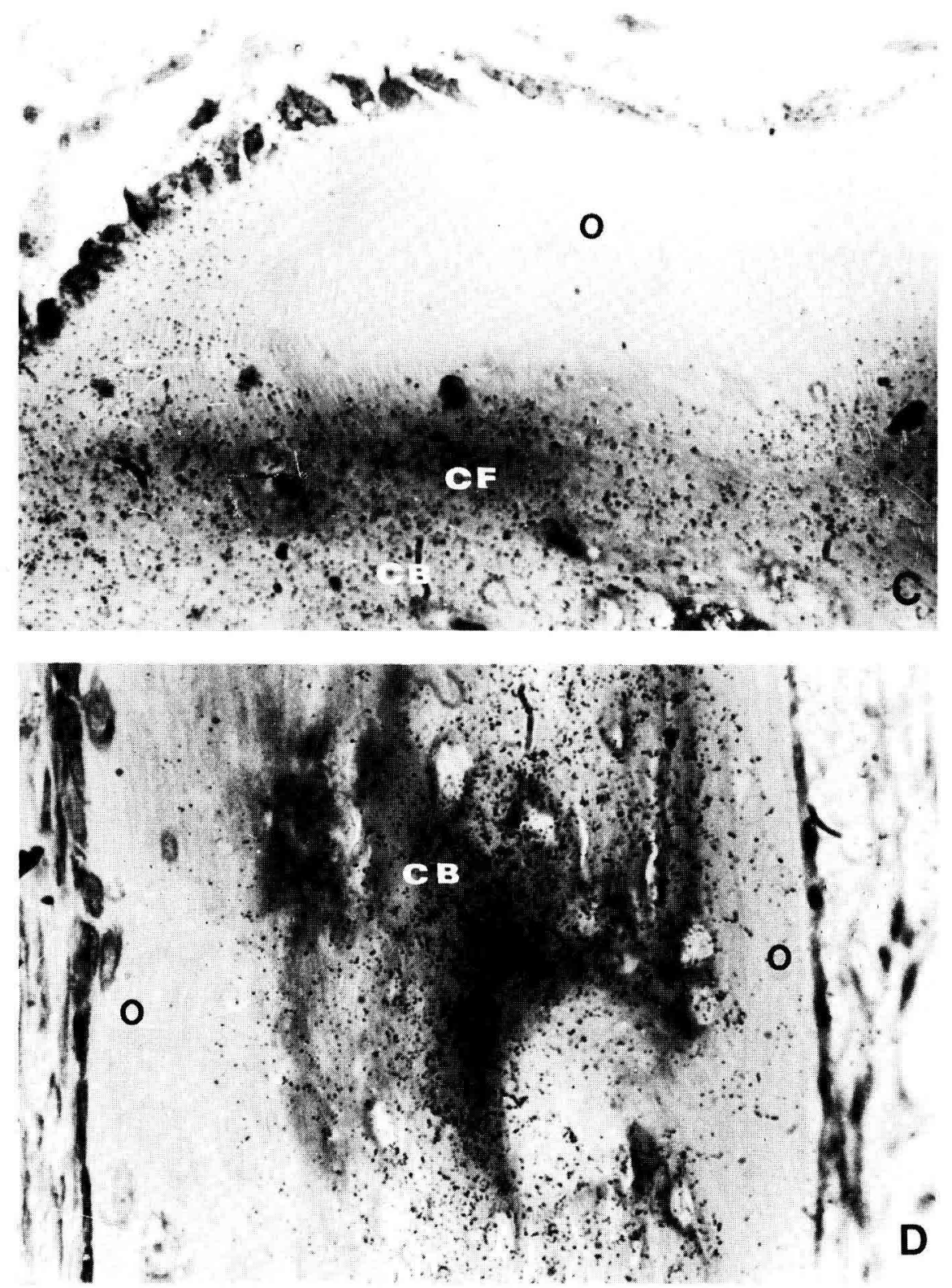

PHOTO C. - Autoradiograph of a diaphyseal vertebral bone from a vitamin D-deficient rat prelabeled with ${ }^{45} \mathrm{calcium}$ and observed $6 \mathrm{~h}$ after injection of $1,25(\mathrm{OH})_{2} \mathrm{D}$. New mineralization of the osteoid $(\mathrm{O})$ is evidenced by the presence of a calcification front (CF). Note that both the old calcified bone (CB) and the new calcification front are heavily labeled with ${ }^{45}$ calcium. Toluidine blue staining : thickness of undecalcified section : $5 \mu \mathrm{m} . \times 512$.

PHOTO D. - Autoradiograph of a diaphyseal vertebral bone from a vitamin D-deficient rat prelabeled with ${ }^{45}$ calcium and observed $24 \mathrm{~h}$ after the injection of $1,25\left(\mathrm{OH}_{2} \mathrm{D}\right.$. Note that osteoid $(\mathrm{O})$ mineralization is extending and that the new calcified bone (CB) remains heavily labeled with ${ }^{45}$ calcium. Toluidine blue staining; thickness of undecalcified section : $5 \mu \mathrm{m} . \times 512$. 
calcified bone matrix was formed, it was heavily labeled with the radioisotope. Twenty-four hours after $1,25(\mathrm{OH})_{2} \mathrm{D}$ injection, the amount of osteoid tissue appeared to decrease and more labeled calcified bone-matrix was observed in treated rats of both experiments.

\section{Discussion.}

The changes observed in serum calcium after $1,25(\mathrm{OH})_{2} \mathrm{D}$ administration in vitamin D-deficient rats are comparable to previously reported data. Initially, $1,25(\mathrm{OH})_{2} \mathrm{D}$ induced a slight but not significant drop in serum calcium. A similar decrease has been reported in vitamin $\mathrm{D}$-deficient dogs soon after the intravenous injection of a comparable dose of $1,25(\mathrm{OH})_{2} \mathrm{D}$ (Oldham et al., 1978). While the cause of the initial decrease in serum calcium is unknown, it should be pointed out that an increase in intracellular calcium uptake is important for the stimulatory effect of vitamine D (Lerner and Gustafson, 1982). On the other hand, the progressive rise in serum calcium starting at time $4-5 \mathrm{~h}$ after $1,25(\mathrm{OH})_{2} \mathrm{D}$ injection probably resulted from a stimulation of intestinal calcium absorption, while the rise in osteoclast number occurring at time $16 \mathrm{~h}$ after the injection of $1,25(\mathrm{OH})_{2} \mathrm{D}$ may have contributed to the late increase in serum calcium.

The relative increase in serum radioactivity at time $2 \mathrm{~h}$ after $1,25(\mathrm{OH})_{2} \mathrm{D}$ injection in rats prelabeled with ${ }^{45}$ calcium resulted from a rapid mobilization of calcium from bone. This rapid bone mobilization of ${ }^{45}$ calcium does not appear to be due to an increase in the osteoclastic population. However, it is possible that $1,25(\mathrm{OH})_{2} \mathrm{D}$ acted by stimulating the activity of existing osteoclasts (Reynolds, 1974). Another explanation may be that $1,25(\mathrm{OH})_{2} \mathrm{D}$ rapidly increased the transport of calcium from the bone fluid compartment to the extracellular compartment through the functional bone cell unit made up of osteocytes connected to osteoblasts and to cells lining the bone surface (Talmage, 1975 ; Davis et al., 1975). The rapid rise in serum specific radioactivity observed shortly after $1,25(\mathrm{OH})_{2} \mathrm{D}$ injection in prelabeled rats may be interpreted as supporting the hypothesis that this metabolite initially increased the flux of calcium out of the bone. The data of experiment 2 also support this hypothesis. In the initial period of time following ${ }^{45}$ calcium injection, the rate of disappearance of the radioisotope from the serum was faster in vitamin D-deficient rats than in the vitamin D-repleted animals, and a single injection of $1,25(\mathrm{OH})_{2} \mathrm{D}$ immediately restored the normal rate of ${ }^{45} \mathrm{calcium}$ loss from the serum. The faster rate of disappearance of ${ }^{45}$ calcium observed in the serum of vitamin D-deficient rats may reflect a decreased efflux of the radioisotope from bone since there is a greater than normal incorporation of ${ }^{45}$ calcium into the caudal vertebrae of vitamin D-deficient rats (Marie, 1976). The immediate restoration of the normal rate of ${ }^{45}$ calcium loss from serum after $1,25(\mathrm{OH})_{2} \mathrm{D}$ injection may indicate that this metabolite increased the rate of efflux of the isotope from bone to serum. On the other hand, the initial drop in serum calcium may have increased PTH secretion, and PTH was found to augment the rate of efflux of calcium from bone to serum (Grubb, Edwards and Talmage, 1977). It is therefore possible that $1,25(\mathrm{OH})_{2} \mathrm{D}$ did not directly affect the mechanism of transfer of calcium from bone to plasma, but that this metabolite 
acted to facilitate the action of PTH. Finally, other mechanisms of calcium mobilization from bone by $1,25(\mathrm{OH})_{2} \mathrm{D}$, such as an increase in bone mineral solubility (Brommage and Neuman, 1979), cannot be excluded. Although the number of osteoclasts was not initially increased, it may also be that the rapid mobilization of bone calcium resulted from an early stimulation of the activity of existing osteoclasts.

From our data, it is not possible to determine whether the effect of $1,25(\mathrm{OH})_{2} \mathrm{D}$ was dose-dependent. It is also difficult to define the duration of the $1,25(\mathrm{OH})_{2} \mathrm{D}$ effect. The rise in serum radioactivity lasted for about 4 to $5 \mathrm{~h}$ and then was abolished. The second part of the biphasic response in serum radioactivity changes might simply reflect the short life of $1,25(\mathrm{OH})_{2} \mathrm{D}$ (Mason et al., 1980) ; it could also result from an increased rate of calcium mixing between compartments since the observed increase in the rate of efflux of calcium to serum must be balanced progressively by an increased rate of calcium influx from blood to bone (Grubb, Edwards and Talmage, 1977). Another possibility is that the recently mobilized calcium returned rapidly to the bone and provided minerals for new bone mineralization.

Impaired mineralization in vitamin D-deficient rats was evidenced by an excessive amount of osteoid associated with a reduced extent of fluorescent mineralizing surfaces compared to the controls. Treatment with $1,25(\mathrm{OH})_{2} \mathrm{D}$ resulted in a rapid increase in the extent of actively mineralizing surfaces although serum calcium remained unchanged. On the other hand, the incorporation of calcein at sites of active bone mineralization began at the time when changes in serum radioactivity were maximal. This observation suggests that the initiation of mineralization was closely related with the rapid mobilization of calcium from older bone. Our autoradiographic data corroborate this hypothesis. Shortly after the injection of ${ }^{45} \mathrm{calcium}$, the radioisotope was predominantly localized in the calcified bone matrix in both vitamin D-deficient and vitamin D-repleted rats. This is in accordance with previous autoradiographic data (Leblond et al., 1959 ; Salomon and Ray, 1966 ; Heeley and Irving, 1973 ; Franck et al., 1974 ; Marie, 1976). The homogeneous distribution of the radioisotope on calcified areas probably was due to a combination of short-term exchange of ${ }^{45} \mathrm{calcium}$ with cold calcium at the surface of hydroxyapatite crystals and the incorporation of the isotope into newly-formed crystals (Vaughan, 1970). It was apparent that the histologically stained calcification front appearing shortly after $1,25(\mathrm{OH})_{2} \mathrm{D}$ injection was heavily labeled with ${ }^{45}$ calcium and that radioisotope labeling extended progressively with time when new bone mineralization continued to develop. In addition, new mineralizing areas began to be labeled at the time when serum specific radioactivity was decreasing. These observations indicate that the radioisotope recently mobilized from bone was rapidly reutilized for new bone mineralization. It is possible that some calcium salts were provided by an initial reduction in the renal excretion of calcium induced by $1,25(\mathrm{OH})_{2} \mathrm{D}$. Our autoradiographic data suggest however that the minerals used for the initiation of bone matrix calcification were mainly of skeletal origin and were provided by local release of calcium from bone. This finding corroborates other experimental studies showing that calcium is conserved locally in bone during the resorption 
that accompanies bone growth (Chen and Klein, 1978) and that most of the resorbed calcium salts are reutilized for new bone formation in vitamin D-deficient or vitamin D-repleted animals (Klein, 1980). Interestingly, we found that the osteoblastic population increased to normal values after treatment with $1,25(\mathrm{OH})_{2} \mathrm{D}$. This might be due to the recruitment of new osteoblasts and/or to the differentiation of preosteoblasts into more mature bone cells. This observation corroborates previous studies showing that active osteoblasts are required for new bone mineralization during the healing of osteomalacia (Marie and Glorieux, 1981). In the present study, however, we found that the osteoblastic surface did not increase before 5-6 $\mathrm{h}$ after $1,25(\mathrm{OH})_{2} \mathrm{D}$ injection ; this would suggest that the initial increase in the extent of actively mineralizing surfaces may not depend on bone-forming cells. Recently, we reported that stimulation of osteoclastic bone resorption induced by the continuous administration of $1,25(\mathrm{OH})_{2} \mathrm{D}$ in normal young mice is associated with enhanced bone mineralization without changes in serum mineral concentrations (Marie and Travers, 1983). This observation, together with the present study, indicate that the beneficial effect of $1,25(\mathrm{OH})_{2} \mathrm{D}$ on bone mineralization is initially closely related with and in part dependent on the stimulatory effect of this metabolite on bone calcium mobilization.

\section{Conclusion.}

To summarize, we found that bone calcium may be rapidly mobilized after a single injection of $1,25(\mathrm{OH})_{2} \mathrm{D}$ in vitamin D-deficient rats. The rapid release of calcium from bone was not associated with an increase in serum calcium or osteoclast number, suggesting that $1,25(\mathrm{OH})_{2} \mathrm{D}$ acts by increasing the rate of efflux of calcium from bone and/or by stimulating the activity of existing osteoclasts. It was found that the calcium released from bone was immediately reutilized for new bone mineralization. It is concluded that the initial improvement of bone mineralization by $1,25(\mathrm{OH})_{2} \mathrm{D}$ depends on the early effect of this metabolite on the mobilization of calcium from bone.

Reçu en janvier 1983. Accepté en juin 1983.

Acknowledgements. - The author wishes to thank Dr. A. W. Norman (Riverside, California, USA) for providing the $1,25(\mathrm{OH})_{2}$ vitamin D. This work was supported by a grant from INSERM.

Résumé. Effets initiaux de la 1,25 dihydroxyvitamine $D$ sur le calcium osseux chez le rat carencé en vitamine $D$.

Les effets précoces de la 1,25 dihydroxyvitamine $D\left[1,25(\mathrm{OH})_{2} D\right]$ sur les mouvements du calcium osseux ont été étudiés chez le rat afin de déterminer si le calcium utilisé au cours de la minéralisation initiale de l'os provient de la résorption préalable de la matrice osseuse. Des rats carencés en vitamine D ont été marqués au ${ }^{45}$ calcium de 10 à 14 jours 
avant d'être traités (protocole 1) ou en même temps (protocole 2) de recevoir $0,125 \mu \mathrm{g}$ de $1,25(\mathrm{OH})_{2} \mathrm{D}$. L'os et le sang ont été prélevés de $30 \mathrm{~min}$ à $24 \mathrm{~h}$ suivant l'injection de $1,25\left(\mathrm{OH}_{2} \mathrm{D}\right.$. On a déterminé les concentrations sériques de calcium stable et radioactif et les vertèbres caudales ont été analysées par histomorphométrie et autoradiographie. Chez les rats du protocole 1, la radioactivité spécifique sérique augmenta rapidement de 1 à $3 \mathrm{~h}$ après l'injection de $1,25(\mathrm{OH})_{2} \mathrm{D}$ par rapport aux rats contrôlés. Chez les rats du protocole 2 , la décroissance plasmatique initiale du ${ }^{45}$ calcium était plus rapide chez les rats carencés non traités que chez les rats normaux mais cette différence fut supprimée chez les rats recevant la $1,25(\mathrm{OH})_{2} \mathrm{D}$. La calcémie et le nombre d'ostéoclastes ne furent pas augmentés initialement, ce qui suggère que l'injection de $1,25(\mathrm{OH})_{2} \mathrm{D}$ eut pour effet d'augmenter le flux sortant de calcium de l'os et/ou de stimuler l'activité des ostéoclastes. Cette mobilisation précoce du calcium fut accompagnée d'une augmentation rapide de l'étendue des surfaces osseuses en voie de minéralisation et fut suivie par une augmentation de l'étendue des surfaces ostéoblastiques et par une incorporation spécifique du calcium radioactif aux sites de minéralisation. Ces résultats indiquent que chez le rat carencé en vitamine $D$, I'amélioration initiale de la minéralisation osseuse apparaissant après l'injection de $1,25(\mathrm{OH})_{2} \mathrm{D}$ résulte en partie de la mobilisation rapide du calcium de l'os anciennement calcifié.

\section{References}

BORDIER P., MARIE P., MIRAVET L., RYCKEWAERT A., RASMUSSEN H., 1976. Morphological and morphometrical characteristics of the mineralization front. A vitamin $D$ regulated sequence of the bone remodeling. In MEUNIER P. J., Lab. Armour-Montagu Imprimeur, Levallois, France, 2nd int. Workshop on Bone histomorphometry, 335-354, Lyon.

BORIS A., HURLEY J. F., TRMAL T., MALLON J. P., MATUSZEWSKI D. S., 1978. Evidence for the promotion of bone mineralization by $1 \alpha, 25$ dihydroxycholecalciferol in the rat unrelated to the correction of deficiencies in serum calcium and phosphorus. J. Nutr., 108, 1899-1906.

BROMMAGE R., NEUMAN W. F., 1979. Mechanism of mobilization of bone mineral by 1,25 dihydroxyvitamin $\mathrm{D}_{3}$. Am. J. Physiol., 237, E 113-E 120.

CHEN T. J., KLEIN L., 1978. Fetal rat bone in organ culture: effect of bone growth and bone atrophy on the comparative losses of ${ }^{45} \mathrm{Ca}$ and ${ }^{3} \mathrm{H}$ tetracycline. Calcif. Tiss. Res., 25, 255-263.

DAVIS W. L., MATTHEWS J. L., MARTIN J. H., KENNEDY J. W., TALMAGE R. V., 1975. The endosteum as a functional membrane, 276-283. In TALMAGE R. V., OWEN M., PARSONS J. A., Calcium regulating hormones, Excerpta med., Amsterdam.

DE LUCA H. F., SCHNOES H. K., 1976. Metabolism and mechanism of action of vitamin D. Annu. Rev. Biochem., 45, 631-666.

FRANCK R. M., FRANCK P., LEROY O., NAGAI N., 1974. Etude ultrastructurale du transfert du ${ }^{45} \mathrm{Ca}$ au cours de l'ostéogenèse. J. Biol. buccale, 2, 299-314.

GRUBB S. A., EDWARDS G., TALMAGE R. V., 1977. Effect of endogenous and infused parathyroid hormone on plasma concentrations of recently administered ${ }^{45}$ calcium. Calcif. Tiss. Res., 24, 209-214.

HAMMOND R. H., STOREY E., 1974. Measurement of growth and resorption of bone in the seventh caudal vertebra of the rat. Calcif. Tiss. Res., 15, 11-20.

HEELEY J. D., IRVING J. T., 1973. A comparison of histological methods for demonstrating calcification. Calcif. Tiss. Res., 12, 169-173.

HOLICK M. F., GARABEDIAN M., DE LUCA H. F., 1976. 1,25 dihydroxycholecalciferol: metabolite of vitamin $D_{3}$ active on bone in anephric rats. Science, 1146-1147.

HOLTROP M. E., COX K. A., CLARK M. B., HOLICK M. F., ANAST C. S., 1981. 1,25 dihydroxycholecalciferol stimulates osteoclasts in rat bones in the absence of parathyroid hormone. Endocrinology, 108, 2293-2301.

KLEIN L., 1980. Direct measurement of bone resorption and calcium conservation during vitamin $D$ deficiency or hypervitaminosis D. Proc. nat. Acad. Sci., USA, 77, 1818-1822.

LEBLOND C. P., LACROIX P., PONLOT R., DHEM A., 1959. Les stades initiaux de l'ostéogenèse. Nouvelles données histochimiques et autoradiographiques. Bull. Acad. roy. Méd. Belg., 24, 421-423. 
LERNER U., GUSTAFSON G. T., 1982. Inhibition of $1 \alpha$-dihydroxyvitamin $D_{3}$ stimulated bone resorption in tissue culture by the calcium antagonist verapamil. Eur. J. clin. Invest., 12, 185190.

MARIE P., 1976. Etude in vitro de l'incorporation et de la localisation autoradiographique du ${ }^{45} \mathrm{calcium}$ dans l'os de rat normal et carencé en vitamine $D_{3}$ DEA de Nutrition, Univ. Paris VI.

MARIE P. J., GLORIEUX F. H., 1981. Stimulation of cortical bone mineralization and remodeling by phosphate and 1,25 dihydroxyvitamin D in vitamin D-resistant rickets. Metab. Bone Dis. Rel. Res., 3, 159-164.

MARIE P. J., TRAVERS R., 1983. Continuous infusion of 1,25 dihydroxyvitamin $D_{3}$ stimulates bone turnover in the normal young mouse. Calcif. Tiss., Int, 35, 418-425.

MARIE P. J., TRAVERS R., GLORIEUX F. H., 1981. Healing of rickets with phosphate supplementation in the hypophosphatemic male mouse. J. clin. Invest., 67, 911-914.

MASON R. S., LISSNER D., POSEN S., NORMAN A. W., 1980. Blood concentrations of dihydroxylated vitamin D metabolites after an oral dose. Brit. Med. J., 1, 449-451.

OLDHAM S. B., SMITH R., HARTENBOWER D. L., HENRY H. L., 1978. Effects of 1,25 dihydroxycholecalciferol on serum calcium, phosphate and immunoreactive parathyroid hormone in dogs. In MASSRY S., RITZ E., RAPADO A., Homeostasis of phosphate and other minerals, 103, 516-519, Excerpta med., Amsterdam.

QUEILLÉ M. L., MIRAVET L., BORDIER P., REDEL J., 1978. The action of vitamin D metabolites in vitamin D-deficient rats. Biomedicine, 28, 237-242.

REYNOLDS J. J., 1974. The role of $1,25(\mathrm{OH})_{2} \mathrm{CC}$ in bone metabolism. Biochem. Soc. Spe. Publ., 3, 91-102.

REYNOLDS J. J., HOLICK M. F., DE LUCA H. F., 1973. The role of vitamin D metabolites in bone resorption. Calcif. Tiss. Res., 12, 295-301.

REYNOLDS J. J., PAVLOVITCH H., BALSAN S., 1976. 1,25 dihydroxycholecalciferol increases bone resorption in thyroparathyroïdectomized mice. Calcif. Tiss. Res., 21, 207-212.

ROGERS A., 1967. Techniques of autoradiography. Elsevier Publ. Co., Amsterdam, London, New York, $335 \mathrm{pp}$.

SALOMON C. D., RAY R. D., 1966. The autoradiographic distribution and localization of $\mathrm{Ca}^{45}$ in undecalcified fresh and devitilazed rat bone autografts. J. Bone Joint Surgery, 48-A, 15751584.

TALMAGE R. V., 1975. Effects of fasting and parathyroid hormone injection on plasma ${ }^{45} \mathrm{Ca}$ concentration in rats. Calcif. Tiss. Res., 17, 103-112.

TANAKA Y., DE LUCA H. F., 1971. Bone mineral mobilization activity of $1,25(\mathrm{OH})_{2}$ cholecalciferol, a metabolite of vitamin D. Arch. Biochem. Biophysics, 146, 574-578.

VAUGHAN J. M., 1970. The physiology of bone. Clarendon Press, Oxford, $325 \mathrm{pp}$.

WEISBRODE S. E., CAPEN C. C., NORMAN A. W., 1978. Ultrastructural evaluation of the effects of 1,25 dihydroxyvitamin $D_{3}$ on bone of thyroparathyroidectomized rats fed a low-calcium diet. Am. J. Pathol., 92, 459-472. 